\title{
Teacher Annotation: Indonesian Students'Learning Behavior in Authoritative Parent Perspective
}

\author{
I. Rohayani \\ Universitas Pendidikan Indonesia \\ Bandung, INDONESIA \\ rohayani94@student.upi.edu
}

\begin{abstract}
The purpose of this article was to identify students learning behavior in parent perspective who claimed authoritatively, and how was school continued what students got from home and implemented it in school climate. This study based on Civic Education (CE) and Intervention Education influence on the character of Young Citizens, the ex-post facto study in 2009. The result of study used to annotate student's learning behavior by a teacher. The steps of further study are observations, interviews, and annotate learning behaviors during three years. Data was collected through students discussed with their own passion, observations and in-depth interview with three students who have three conditioned teachers' experiences. The annotated result is the most effective learning processes guided by the authoritative teacher. This affected not only learning behavior but teaching behavior improvement also.
\end{abstract}

Keywords: three years annotations, interfering parent and school, intervention.

\section{INTRODUCTION}

Teacher as a generic transform of learning processes has the chance to implement his ability to build student's character. The aims of Education is to prepare and develop student's ability be a responsible citizen. It needs involving formal and informal institution toward the aims. So many social and political researcher characterized it. Almost of results have the same conclusion, a responsible citizen is a democratic citizen. Democratic citizen dealing with internalization as potential citizenry from his/her family and learning processes from school. Family and school influent student to engage in the democratic citizen. Student's potential citizenry characterized by how citizen can solve the problem, have sense of socially sensitiveness, country loved, devote to god and good behave, critical thinking, public policy involving, informed citizen, and undertaking citizen participation. It won't work in every socially taking role if those characterized are not implement in daily conduct. The system will punish [1].

This article described how Indonesian parent involves in informal education to prepare their children be a democratic citizen through civic mindedness, religion, democratic rules, and a public morality. Thus, parents and school have to cooperate preparing students engage in social and political life. In experimental research of parent involving model in school, parent collaborated with the teacher have solved social and learning problem. And it works. This study showed authoritative parent and teacher effected students activity be an active citizenship. Active citizenship supported socially taking the role in daily conduct and make democracy works the way what supposed to be. It said in Europe council as the power of state constituents to make country life long in sovereignty "... to exercise and defend their democratic rights and responsibilities in society, to value diversity and to play an active part in democratic life. "Citizens cannot fulfill these ambitious tasks adequately without specific competences; that is, citizens need to have "... a combination of knowledge, skills, attitudes, and values" at their disposal enabling them "... to become an active citizen" [2].

Further, this study annotated by an author in three learning behavior categorized are self-motivation to criticized social issues, sense of responsibility in task completely, and discipline. The shreds of evidence have taken during three years learning processes by observation, interview, and indepth discussed with three students who learned with different teacher style. This study was to answer the learning behavior in authoritative parent perspective involved in a school program to prepare an active citizenship.

\section{TEACHER ANNOTATION}

This study recorded how students give respond to teacher's intervention. It shows learning the behavior of students in 3 years during Civic Education (CE) study. The steps of study are student's background mapping (parent, education, economics condition, motivation, etc.) that researched in 2009 and reviewed in 2012 for the following student, comparing a student who study with different teacher, and annotate the recent condition when students teach by a teacher. The sample is only one level of students, twelve grade. Teacher annotates learning behavior in a recent study in the same subject for rarely students.

In 2009, the result of the study was $25 \%$ of interfering Civic Education and Parent to student's character building in the ex-post facto study. The quantitative research chose in this study. In this study took data based on Questionnaire about student's perception of civic education study and parent intervention to build their good character as a young citizen. The ordinal measurement is to describe of students interest, attitude, or behavior divided by a student's certain object interest. For example, based on the good character of respondent moral awareness can berating by "strongly agree", "agree", "disagree", and "strongly disagree". If the respondent "strongly disagree" marked 1, "disagree" for 2, "agree" is 3, and "strongly agree" is 4 , these numbers only to shows respondent sequence, not the mark of variable respondents.

For civic education interfere measured by SSHA scale (Survey of Study of Habits and Attitudes). The pattern's scale is "strongly often", "often", "occasionally", and "never". The mark for "strongly often" is 4, 3 for "often", "occasionally" is 2 , and 1 for "never". Civic competences measured by multiple choice questionnaires. 
The intervention education data based on Value Clarification rank order. The respondents make some steps to analyze conditions in practical interfering of parent and make the judgement [3]. Parent interfered type: (a) authoritative, (b) authoritarian, and (c) permissive with the sequence mark 3, 2, and 1. for the last step to cultivate database to transform the ordinal scales to interval scales used MSI (Method of Successive Interval) for every questionnaire items. The result shows as follow:

1) Both of Variables X1 (Civic Education Learning Processes) and X2 (Intervention Education) affect contributed to $Y$ (Young Citizens'character) is $25 \%$

2) The magnitude of X1 affected directly to $Y$ is $17,97 \%$ and indirectly is $1,086 \%$

3) $X_{2}$ contributed directly to $Y$ is $4,79 \%$ and indirectly is $1,086 \%$

4) For immeasurable factor to young citizens character is $74,99 \%$. This variable assumed comes up from external findings factor, such as extracurricular activities, school voluntary program, school and family environment, teacher style, etc.

In 2012, the study shows a percent increased. This shows how teacher applies method, models, media, giving reinforcement, evaluate, and humane conduct in class. The students with authoritative parent interfered are the object of teacher annotations. There are three students categorized learn $\mathrm{CE}$ guided by a teacher whole levels (nurturing teacher), one student learns CE with three different teachers in the whole level (has different teacher each level), and one student learn $\mathrm{CE}$ guided by two teacher whole levels.

During 2013 - august 2015 teacher annotated learning behavior as the impact of school and parent intervention. The categorizes of annotation are self-motivation to criticized social issues, sense of responsibility in task completely, and discipline.

This study also gives the reason of teaching method in learning processes. It is not for judging professional or not, but to describe learning process effectiveness. In this case showing how learning process responded well by the student to implement educational aims, focusing in good behave.

\section{LEARNING BEHAVIOR IN INDONESIAN CULTURAL PERSPECTIVE}

The students who learn by their own goals are better than the one who forced. In my perspective, if a teacher keeps going to continue what students get from home, it make easier to motivate them doing better. The teacher annotation result of this study has particular findings:

1) The first year students (2013) who have learned Civic education guided by two or three teachers.

- The students making comparative unwrite annotations. They give some information of teaching conduct of each teacher. Then, they compare it and prepare themselves if they meet one of this teacher in next level.
- The teacher who authoritative has good respond from the students. They show respect to learning and interest in social issues, responsible for completing the task assignment, and good attendance.

- The authoritarian teacher has very good respond from the students, but they give arguments that if they did not do the task they will get punishment. The students strongly doing task completely and discipline, but the lack of interested for social issues and discussed. The annotation said students doing everything under pressure.

- The permissive one is student's beloved. They do what they want to do. Some of the students doing the task because they respect the teacher, but almost students didn't do it. There are no reasons for them to do the task. Finally, they will get the good mark for every student. Some students have incompletely task, irresponsible, and indiscipline.

2) The second year (2014), two teachers guide the same level with the same students. They have the distinctive intervention, Authoritative and permissive. There are some recorded in annotation of student's learning behavior, as follow:

- The students who study with authoritative and authoritarian teacher taught by authoritative, they are comfortable. They did assignment completely, have good responsible, and good attendance. The students who have the study with permissive give some more responsibility. They have some reason to do that. They argued they have some information for obedience and unobedience students will get consequences. So they prepare to face it. But there are students who still have originally conducted. They changed after they got interfered from the teacher.

- The students who study guided by permissive one have the different perspective. The students who came up from the authoritative have complained. They want to keep good behavior but can't do that. Nevertheless, some of the students more comfortable with this situation, they feel relieved from the obedience must. The students from authoritarian feel better, but some of them most comfortable with an originally situation.

- From the situation of three kinds of students annotated missed authoritative one. They have argumentations for the reasons: they required the informed reason to do task assignment, responsibility, and discipline.

3) The third year on July - August 2015, all students learned with the authoritative teacher. almost $70 \%$ students have task assignment completely, good respond to learning, and disciplined. They show obedient of timetable, interested in solving social issues : discussed, researched, and presented. They oversee learning processes with a teacher.

These findings indicated authoritative parent and teacher more instinctively give a good reason and understanding to the students for their conduct, so they will give attentions to responsibility and rules [4]. There must be models to guide authoritative parent and teacher. it comes up be reasoning for the pedagogical base. There are philosophically pedagogic 
method influent authoritative perspectives: perennials and cultural intervention.

\section{A. Students'Learning behavior in Authoritative Parent Perspective}

I believe so many researchers argue that involving the parent in schooling program is one of the student's achievement factor [5]. And the most important is family characterized practical models on educating style. There is so many precious impact for parent involving in educational processes such as motivate to increase mark reports, students engagement in the study and social life [5]. The authoritative parent interested to get involve in school programs. They have owned model to educate moral and responsibility for their children. In my study I found parent teach that model based on their belief in a religious way. Their perennial system authority taught from the previous generation. For example, in Sundanese cultural (one of Indonesian tribe) there is an idiom that "Agama Jadi tetengger" it means religion be your guidance in life. Everything must be based on a religious system. For many reasons of Indonesian people believe on their holy books. So many educational wisdom indeed. If we noticed this, most of the children accepted it as their educational good goals. It caused assumption that model advocated two dimensions demandingness and responsiveness to treat children. These dimensions tend to the authoritative parent if they applied more than standard [6]. So as School must be accepted that perspective. In perennials pedagogical philosophies, teacher who has good religion knowledge and superior within intervened students character, so that they engaged. [7].

In this study, I found kinds of learning behavior responds in $\mathrm{CE}$ with a different style of teachers during three years. The students who give more attentions for social issues, doing their task assignments, and a good attendance is dealing with teacher involving and giving respect for student's work. It shows teacher has interested in emotional and professional capacity to notice the student learning behavioral changes at upward level [6]. It is authoritative teacher style. That teacher needed to pursuit student's good achievement and future perspective school. Contrary in the condition that students doing their homework in under pressure, discipline, but not giving for social interest is dealing with the teacher who ask for many tasks but not giving motivation. It is authoritarian teacher style. The last teacher style is permissive. In this annotation shows the students do not have good reason to do their task because the rules always changed. The teacher has no involving in classroom climate. Sometime teacher doesn't have the interest to give a challenge. The annotations show teacher interfered students behavioral learning. Thus impacted to how children or students build their capacity as a human being and a good learner [6].

\section{B. Teacher Annotation to improve Learning Processes}

This study focused on recording students learning behavior on $\mathrm{CE}$ by personal written. The author wanted to show that teacher can make 'self' writing for research. This aimed is to improve his/her learning processes. This inspired by foreigner linguistic teacher who gives annotated feedback to give an assessment. When the teacher gives some correction in his assessment, he gives a note to the student to show incorrect word. That experience gives some data that teacher was detected deficiency of teaching processes. These data comes up and give some idea to change teaching style and get more benefits for students [8]. This idea becomes interesting when author determined students real behavior annotation to improve teaching style. The teacher must have a set of a plan to know what the annotation's goal, involving in classroom climate, or at least observed and interviewed the research object,[9]. This study needs more than one data as the empirical object. It also needs some reasoning explanation in other research or generalization to support this writing. The explanation must be easy to earn by a reader and himself. And the most important is the information not in common sense but giving logic argumentation [9].

For further, this writing is not only for figuring, describing, or determining something, but give some information for a reader and especially for the writer in professional vocation. In this study, the teacher makes some annotation to make historical portfolio in teaching and learning processes. it focused on students learning behavior for social issues, task assignment responsibility, and discipline.

\section{CONCLUSION}

Annotated behavior of learning was collected of most eventually students shown in fulfilled their learning engagement. The teacher can take benefits of these annotations to improve his professionalism, students portfolio assessment, and parent report shreds of evidence. It also is shown demandingness and responsiveness teacher, students, and parent involving to developed learning environment. This study has methodological research deficiency. It needs improvement in an empirical and theoretical analysis. It gave the experience of experimental research in collaboration both of quantitative in recent and qualitative approaches in later.

\section{ACKNOWLEDGMENT:}

Drs. H. Encang Iskandar,M.Pd. (The Principle of SMA Negeri 3 Bandung); Students as data collector: Muhammad Mara Ikhsan, R. Mochammad Iqbal, Yasmin Fatinah; colleagues: Dra. Yattini, M.Pd., Dra. R. Dewi Kusumowardhani, Drs. Irvan Bahtiar, Drs. Rohmat Herawan, Wiwin Herawati,M.Pd.

\section{REFERENCES}

[1] Gunsteren, Herman Van. (1998). "A Theory Of Citizenship Organizing Plurality in Contemporary Democracies", USA: Westview Press

[2] Print, Murray \& Lange, Dirk. (2013). "Civic Education and competences for Engaging citizens in Democracies", Van Deth, Jan W . "Active Citizenship" (page. 9-21). Rotterdam/Boston/Taipei : Sense Publisher

[3] Kirschenbaum, Howard. (2013). "Value Clarification in Counseling and Psychotheraphy: Practical Strategies for Individual and Group Settings". Oxford: Oxford University Press. eBook

[4] Lickona, Thomas., (1992). "Educating For Character How Our Schools Can Teach Respect and Responsibility", New York-TorontoLondon-Sydney-Auckland: Bantam Books

[5] Darch, Craig. Yu Miao. Shippen, Peggy (2004). "A Model for Involving Parents of Children With Learning and Behavior Problems in the School" Spring; ProQuest

[6] Walker, Joan M.T., (2008) "Looking at Teacher Practices Through the Lens of Parenting style" page 218-240 " The Journal of Experimental Education, 2008,76". Long Island University: Heldref Publication

[7] Brameld, Theodore. (1955). Philosophies of Education. New YorkChicago-San Francisco-Toronto-London: Holt, Rinehart, and Winston

[8] Haoucha, Malika., (2012). "The Role of Peer Feedback, Teacher Written and Taped Commentary in Enhancing Revision and Improving 
Text Quality" International Journal of Art and Science, University Publication.net

[9] Wall, Susan V., (2004). "Writing the "self" in teacher research: The Potential Powers of a New Professional Discourse" pg. 289-317. "English Education; Jul 2004, 36, 4". ProQuest Professional Education 